\title{
Analisis Kemampuan Representasi Matematis Siswa dalam Menyelesaikan Soal Cerita Program Linear
}

\author{
Azka Miladiah', a), Nurhaida ${ }^{2, b)}$, Nurul Ikhsan Karimah ${ }^{3, c)}$ \\ ${ }_{1,3}^{1,3}$ Prodi Pendidikan Matematika Universitas Swadaya Gunung Jati \\ ${ }^{2}$ MAN 1 Kabupaten Cirebon

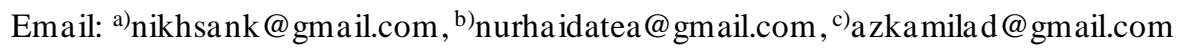

\begin{abstract}
Abstrak
Penelitian ini bertujuan untuk mengetahui bagaimana kemampuan representasi matematis siswa dalam menyelesaikan soal-soal cerita yang berkaitan dengan program linear. Adapun yang menjadi latar belakang penelitian ini adalah karena kemampuan representasi matematis merupakan kemampuan yang perlu dimiliki oleh setiap siswa dalam menghadapi berbagai permasalahan kehidupan sehari-hari. Metode yang digunakan dalam penelitian ini a da lah metode kualita tif dengan sampelnya adalah siswa MAN 1 Kabupaten Cirebon kelas XI IIS 1 sebanyak 34 orang. Instrumen dalam penelitian ini berupa tes kemampuan represenasi matematis sebanyak 2 butir soal uraian yang disesuaikan dengan indikator. Dari hasil penelitian ini diperoleh kesimpulan bahwa (1) kemampuan representasi visual siswa berupa tabel pada materi program linear termasuk dalam kriteria tinggi dengan persentase $84,37 \%$ dan rata-rata skor 25,31 ; (2) kemampuan representasi persamaan matematis siswa berupa model matematika pada materi program linear termasuk dalam kriteria sedang dengan persentase 65,9\% dan rata-rata skor 13,18; (3) kemampuan representasi kata-kata siswa berupa langkah-langkah penyelesaian masalah termasuk dalam kriteria rendah dengan persenta se 47,44\% dan rata-rata skor 23,72; dan (4) kema mpuan representasi matematis siswa secara keseluruhan pada materi program linear terma suk dalam kriteria sedang dengan persentase 64,08 dan rata-rata skor 64,08 .
\end{abstract}

Kata kunci: representasi, soal cerita, program linear.

\section{PENDAHULUAN}

Matematika merupakan salah satu mata pelajaran yang wajib dipelajari, terutama di sekolahsekolah formal. Matematika bukanlah pengetahuan menyendiri yang dapat sempurna karena dirinya sendiri, tetapi dengan adanya matematika diharapkan dapat membantu manusia dalam memahami dan menyelesaikan permasalahan kehidupan sehari-hari. Oleh karenaitu matematika perlu dipahami dan dikuasai oleh segenap lapisan masyarakat. Selain itu, sebagaimana yang tercantum dalam standar isi untuk satuan pendidikan dasar dan menengah mata pelajaran matematika telah disebutkan bahwa mata pelajaran matematika perlu diberikan kepada semua peserta didik mulai dari sekolah dasar untuk membekali peserta didik dengan kemampuan-kemampuan matematis. Harapannya dengan pembelajaran matematika siswa dapat memiliki kemampuan-kemampuan tersebut terutama yang mengarah kepada kemampuan representasi matematis. Kemampuan ini dapat membantu siswa dalam membangun konsep dan menyatakan ide-ide matematis.

Hal tersebut didukung oleh NCTM (2000: 67) yang menyatakan bahwa terdapat lima daya matematis yang harus dimiliki oleh siswa dalam pembelajaran matematika, meliputi: (1) kemampuan penyelesaian masalah (problem solving), (2) kemampuan penalaran dan pembuktian (reasoning and proof), (3) kemampuan komunikasi matematis (communication), (4) kemampuan 
koneksi matematis (connections), dan (5) kemampuan representasi matematis (representation). $\operatorname{NCTM}(2000: 280)$ juga mengemukakan bahwa representasi sangatlah penting dalam pembelajaran matematika. Siswa dapat mengembangkan dan memperdalam pemahaman tentang konsep dan hubungan matematika ketika mereka membuat, membandingkan, dan menggunakan berbagai representasi. Representasi seperti objek manipulatif, gambar, tabel, grafik, dan simbol juga membantu siswa mengkomunikasikan pemikiran mereka. Kemampuan representasi yang dikuasai dengan baik akan membantu siswa menjadikan gagasan-gagasan matematis lebih konkrit, artinya apabila representasi yang digunakan sesuai dengan masalah yang diberikan maka suatu masalah yang rumit akan menjadi lebih sederhana dan sebaliknya apabila tidak sesuai maka masalah tersebut akan sukar dipecahkan.

Kemampuan representasi sangat penting dimiliki oleh siswa karena mampu mempermudah siswa mempelajari matematika, sebagaimana pernyataan NCTM sebagai berikut:

Representation is central to the study of mathematics. Students can develop and deepen their understanding of mathematical concepts and relationships as they create, compare, and use various representations. Representations - such as physical objects, drawings, charts, graphs, and symbols — also help students communicate their thinking.

Representasi adalah pusat dari pembelajaran matematika. Siswa dapat mengembangkan dan memperdalam pemahaman mereka akan konsep dan hubungan antarkonsep matematika yang telah mereka miliki melalui membuat, membandingkan dan menggunakan representasi.

Mudzakir mengelompokkan representasi matematis ke dalam empat ragam representasi utama, yaitu representasi visual, representasi gambar, persamaan matematis, dan kata-kata. Representasi visual adalah representasi yang menyajikan informasi dari suatu representasi ke representasi diagram, grafik, atau tabel dan menggunakan representasi visual untuk menyelesaikan masalah; representasi gambar yaitu membuat pola-pola geometri untuk memperjelas masalah dan memfasilitasi penyelesaiannya; persamaan matematis yaitu membuat persamaan matematika dari representasi lain yang diberikan, membuat konjektur dari suatu pola bilangan, dan menyelesaikan masalah dengan melibatkan persamaan matematis; kata-kata yaitu membuat situasi masalah berdasarkan data representasi yang diberikan, menuliskan interpretasi dari suatu representasi, menuliskan langkah-langkah penyelesaian masalah matematika dengan kata-kata, menyusun cerita yang sesuai dengan suatu representasi yang disajikan, dan menjawab soal dengan menggunakan kata-kata (dalam Eka \& Ridwan, 2015). Dalam penelitian ini, representasi matematis dibatasi pada tiga ragam representasi utama yaitu representasi visual (menyajikan kembali informasi dari suatu representasi ke representasi tabel), persamaan matematis (membuat persamaan matematika dari representasi lain yang diberikan) dan kata-kata (menyelesaikan permasalahan soal cerita secara sistematis).

Dalam kehidupan sehari-hari, seringkali kita menemukan permasalahan-permasalahan nyata yang berkaitan dengan program linear. Sebagai contoh, dalam memproduksi suatu barang kita diharapkan untuk memproduksi barang sebanyak-banyaknya dengan biaya produksi paling sedikit supaya mendapat keuntungan yang besar. Hal tersebut menunjukkan betapa pentingnya peranan kemampuan representasi matematis dalam pembelajaran matematika. Oleh karena itu, peneliti tertarik untuk menganalisis kemampuan representasi matematis dalam menyelesaikan masalahmasalah nyata yang berkaitan dengan materi program linear.

\section{METODE}

Metode penelitian yang digunakan di sini adalah metode deskriptif. Nawawi (2015: 65) mengemukakan bahwa metode penelitian adalah cara yang digunakan untuk memecahkan masalah atau mencapai tujuan dengan menggunakan langkah-langkah yang relevan. Metode deskriptif dapat diartikan sebagai prosedur pemecahan masalah yang diselidiki dengan menggambarkan atau menuliskan keadaan subjek/objek penelitian pada saat sekarang berdasarkan fakta-fakta yang tampak sebagaimana adanya (Nawawi, 2015: 67). Bentuk penelitian ini adalah bentuk penelitian kasus. Penelitian deskriptif dalam penelitian ini dimaksudkan untuk mengungkap dan mendeskripsikan kemampuan representasi matematis pada materi program linear di Madrasah 
Aliyah Negeri 1 Kabupaten Cirebon. Subjek dalam penelitian ini adalah satu kelas siswa kelas XI IIS 1 Madrasah Aliyah Negeri 1 Kabupaten Cirebon sebanyak 34 siswa dengan syarat siswa telah selesai mempelajari materi program linear pada kelas XI semester 1. Objek dalam penelitian ini adalah kemampuan representasi matematis siswa dalam menyelesaikan soal cerita materi Program Linear. Prosedur dalam penelitian ini terdiri dari 3 tahap, yaitu: (1) tahap persiapan; (2) tahap pelaksanaan; dan (3) tahap akhir.

\section{Tahap Persiapan}

Langkah-langkah yang dilakukan pada tahap persiapan antara lain: (1) menyiapkan instrumen penelitian berupa kisi-kisi soal tes kemampuan representasi, soal tes kemampuan representasi matematis siswa, alternatif kunci jawaban soal kemampuan representasi matematis, rubrik penskoran tes kemampuan representasi matematis dan pedoman wawancara; (2) melakukan uji validasi instrumen penelitian; (3) melakukan revisi instrumen penelitian berdasarkan hasil validasi; (4) melakukan uji coba soal tes; dan (5) melakukan penghitungan data hasil uji coba soal tes (validitas, reliabilitas, dan daya pembeda).

\section{Tahap Pelaksanaan}

Langkah-langkah yang dilakukan pada tahap pelaksanaan antara lain: (1) memberikan soal tes kemampuan representasi matematis kepada satu kelas siswa kelas XI IIS 1 Madrasah Aliyah Negeri 1 Kabupaten Cirebon dengan alokasi waktu pengerjaan soal 90 menit; dan (2) menganalisis jawaban siswa.

\section{Tahap Akhir}

Langkah-langkah yang dilakukan pada tahap akhir antara lain: (1) mendeskripsikan hasil tes dalam bentuk narasi yang menggambarkan bagaimana kemampuan representasi matematis siswa dalam menyelesaikan soal cerita pada materi program linear; (2) membuat

kesimpulan; dan (3) menyusun laporan penelitian.

\section{HASIL DAN PEMBAHASAN}

\section{Hasil Penelitian}

Tes kemampuan representasi matematis siswa yang diberikan berjumlah 2 soal yang dibuat dalam bentuk uraian. Setelah memberikan tes tertulis mengenai kemampuan representasi matematis kepada 34 siswa kelas XI IIS 1 Madrasah Aliyah Negeri 1 Kabupaten Cirebon, tes tersebut kemudian diberikan skor sesuai dengan kriteria penskoran yang tercantum dalam pedoman penskoran. Selanjutnya diberikan persentase dari skor yang didapat dan dianalisis. Berikut akan disajikan hasil tes kemampuan representasi matematis siswa.

TABEL 1. Hasil Tes Kemampuan Representasi Matematis

\begin{tabular}{ccccc}
\hline $\begin{array}{c}\text { Kemampuan } \\
\begin{array}{c}\text { Representasi } \\
\text { Matematis }\end{array}\end{array}$ & Tabel & $\begin{array}{c}\text { Model } \\
\text { Matematika }\end{array}$ & Kata & Total \\
\hline Skor Maksimum & 30 & 20 & 50 & 100 \\
Rata-rata Skor & 25,31 & 13,18 & 23,72 & 64,08 \\
Persentase & $84,37 \%$ & $65,9 \%$ & $47,44 \%$ & 64,08 \\
Kategori & Tinggi & Sedang & Rendah & Sedang \\
\hline
\end{tabular}

Berdasarkan pada tabel 1, rata-rata skor yang diperoleh siswa pada indikator representasi visual berupa tabel adalah 25,31 dengan persentase $84,37 \%$ sehingga kategori representasi visual berupa 
tabel adalah tinggi. Rata-rata skor yang diperoleh siswa pada indikator representasi persamaan matematis berupa model matematika adalah 13,18 dengan persentase $65,9 \%$ sehingga representasi persamaan matematis berupa model matematika adalah sedang. Rata-rata skor yang diperoleh siswa pada indikator representasi kata berupa langkah-langkah penyelesaian masalah adalah 23,72 dengan persentase $47,44 \%$ sehingga representasi kata berupa langkah -langkah penyelesaian siswa adalah rendah. Sedangkan rata-rata gabungan ketiga skor representasi diatas adalah 64,08 dengan persentase 64,08\% sehingga dari seluruh representasi yang diujikan pada siswa kelas XI IIS 1 Madrasah Aliyah Negeri 1 Kabupaten Cirebon memiliki representasi sedang.

TABEL 2. Langkah-langkah Penyelesaian yang Dilakukan oleh Siswa

\begin{tabular}{cccccccccc}
\hline & \multicolumn{3}{c}{ Tabel } & \multicolumn{4}{c}{ Model Matematika } & \multicolumn{3}{c}{ Kata } \\
\cline { 2 - 10 } & A & B & C & D & E & F & G & H & I \\
\hline Jumlah & 26 & 14 & 10 & 30 & 4 & 29 & 16 & 8 & 5 \\
\hline $\begin{array}{c}\text { Persentase } \\
(\%)\end{array}$ & 76,47 & 41,17 & 29,41 & 88,23 & 11,76 & 85,29 & 47,06 & 23,53 & 14,71 \\
\hline
\end{tabular}

Indikator representasi visual berupa tabel pada tabel 2, sebanyak 26 siswa yang menuliskan apa yang diketahui ke dalam bentuk tabel secara lengkap. Sebanyak 14 siswa yang menuliskan satuan pada tabel, dan sebanyak 10 siswa tidak menyamakan satuan pada tabel tersebut. Pada representasi persamaan matematis sebanyak 30 siswa yang menuliskan permisalan dengan variabel, sebanyak 4 siswa yang menuliskan model matematika secara lengkap, dan sebanyak 29 siswa menuliskan fungsi tujuan. Sedangkan pada representasi kata sebanyak 16 siswa yang mencari nilai variabel, sebanyak 8 siswa yang membuat grafik sesuai dengan titik potong pada model matematika, dan hanya 5 orang yang memberikan kesimpulan.

\section{Pembahasan}

Penelitian ini bertujuan untuk mengetahui kemampuan representasi matematis siswa dalam menyelesaikan soal cerita materi program linear di Madrasah Aliyah Negeri 1 Kabupaten Cirebon. Berdasarkan hasil data yang diperoleh kemampuan representasi matematis siswa secara keseluruhan berada pada kategori sedang dengan rata-rata skor adalah 64,08 dan persentase 64,08\%. Dibawah ini akan dikaji pembahasan mengenai kemampuan representasi matematis siswa pada tiap representasi.

\section{Representasi Visual Berupa Tabel}

Pada soal nomor 1 dan 2, rata-rata skor yang diperoleh siswa pada indikator representasi visual berupa tabel adalah 25,31 dengan persentase $84,37 \%$. Hal ini menunjukkan bahwa kemampuan representasi visual siswa berupa tabel termasuk dalam kategori tinggi. Berdasarkan tabel 2, dapat dilihat bahwa siswa yang menuliskan apa yang diketahui ke dalam bentuk tabel dengan lengkap ada 26 siswa dengan persentase $76,47 \%$. Siswa yang menuliskan satuan hanya 14 siswa dengan persentase $41,17 \%$. Dan siswa yang tidak mengubah satuan ada 10 siswa dengan persentase $29,41 \%$.

Pada langkah penyelesaian semua siswa membuat tabel tetapi ada siswa yang benar memasukkan ke dalam tabel ada juga yang masih keliru atau kurang. Kebanyakan siswa tidak menuliskan satuan berat yang ada pada soal. Sehingga jika soal tersebut dilanjutkan ke model matematika dan siswa kurang teliti bisa menyebabkan kesalahan jawaban. Dari hasil penelitian, kebanyakan siswa cenderung tidak mengubah satuan, tetapi siswa hanya menuliskan apa yang diketahui dan menuliskan satuannya tanpa mengubah satuan. Ini dikarenakan siswa lebih sering menyebut angkanya saja daripada menyebutkan dengan len gkap angka dan satuannya, mereka beralasan supaya pengerjaannya lebih cepat. 


\section{Representasi Persamaan Matematis Berupa Model Matematika}

Pada soal nomor 1 dan 2, rata-rata skor yang diperoleh siswa pada indikator representasi persamaan matematis berupa model matematika adalah 13,18 dengan persentase $65,9 \%$. Hal ini menunjukkan bahwa kemampuan representasi persamaan matematis siswa berupa model matematika termasuk dalam kategori sedang. Berdasarkan tabel 2, dapat dilihat bahwa siswa yang membuat permisalan dengan variabel sebanyak 30 siswa dengan persentase $88,23 \%$. Siswa yang membuat model matematika dengan lengkap sebanyak 4 siswa dengan persentase $11,76 \%$. Dan siswa yang menuliskan fungsi tujuan sebanyak 29 siswa dengan persentase $85,29 \%$. Jadi, dapat disimpulkan pada representasi persamaan matematis berupa model matematika kebanyakan siswa membuat permisalan dengan dengan variabel dan menuliskan fungsi tujuan, tetapi masih banyak siswa yang tidak membuat model matematika dengan lengkap. Pada langkah pengerjaan ini siswa kebanyakan tidak menuliskan persamaan $x \geq 0$ dan $y \geq 0$, sehingga menyebabkan model matematika menjadi kurang lengkap. Padahal di setiap pembelajaran materi program linear selalu diajarkan untuk selalu menuliskan persamaan dengan lengkap sehingga mendapatkan jawaban yang tepat. Dari hasil penelitian, diduga kelemahan yang mereka hadapi pada soal nomor 2 adalah mereka hanya menuliskan apa yang terdapat di soal cerita untuk dituliskan di model matematika.

\section{Representasi Kata Berupa Langkah-Langkah Penyelesaian Masalah}

Pada soal nomor 1 dan 2, rata-rata skor yang diperoleh siswa pada indikator representasi kata berupa langkah-langkah penyelesaian masalah adalah 23,72 dengan persentase 47,44\%. Hal ini menunjukkan bahwa kemampuan representasi kata berupa langkah-langkah penyelesaian siswa termasuk dalam kategori rendah. Berdasarkan tabel 2, dapat dilihat bahwa sebanyak 16 siswa yang mencari nilai variabel, sebanyak 8 siswa yang membuat grafik sesuai dengan titik potong pada model matematika, dan han ya 5 orang yang memberikan kesimpulan.

Dari langkah pengerjaan yang dilakukan oleh siswa, dapat dilihat tidak adanya siswa yang membuat tabel diduga karena mereka merasa tidak perlu membuat tabel langsung membuat model saja. Dalam membuat model matematika mereka tetap tidak membuat persamaan dengan lengkap sehingga membuat model menjadi tidak lengkap. Sedangkan untuk penyelesaiannya kebanyakan siswa tidak menyelesaikan sampai menemukan jawaban akhir diduga mereka lupa caramengerjakan materi program linear dalam memodelkan persamaan matematikanya.

Adapun soal tes kemampuan representasi matematis pada materi program linear yang diberikan pada siswa adalah sebagai berikut.

1. Seorang pembuat kue mempunyai $4 \mathrm{~kg}$ gula dan $9 \mathrm{~kg}$ tepung. Untuk membuat se buah kue jenis A dibutuhkan 20 gram gula dan 60 gram tepung, sedangkan untuk membuat sebuah kue jenis B dibutuhkan 20 gram gula dan 40 gram tepung. Jika kue A dijual dengan harga Rp4.000,00 per buah dan kue B dijual dengan harga Rp3.000,00 per buah, tentukan pendapatan maksimum yang diperoleh pembuat kue tersebut!

2. Seorang pemborong memproduksi dua jenis bentuk pagar, yaitu pagar A dengan harga Rp30.000,00 per $\mathrm{m}^{2}$ dan pagar B dengan harga $\mathrm{Rp} 45.000,00$ per $\mathrm{m}^{2}$. Setiap $\mathrm{m}^{2}$ pagar jenis A membutuhkan $4 \mathrm{~m}$ pipa besi dan $6 \mathrm{~m}$ pipa beton. Adapun tiap $\mathrm{m}^{2}$ pagar jenis $\mathrm{B}$ membutuhkan $8 \mathrm{~m}$ pipa besidan $4 \mathrm{~m}$ besi beton. Persediaan yang ada $640 \mathrm{~m}$ pipa besi dan $480 \mathrm{~m}$ pipabeton. Berapa banyak tiap-tiap pagar yang harus dibuat untuk mendapatkan hasil penjualan maksimum?

GAMBAR 1. Instrumen Tes Kemampuan Representasi Matematis pada Materi Program Linear 


\section{PENUTUP}

\section{Kesimpulan}

Berdasarkan hasil penelitian dan pembahasan yang telah dijelaskan, kesimpulan yang diperoleh adalah: (1) kemampuan representasi visual siswa berupa tabel pada ma teri program linear termasuk dalam kriteria tinggi dengan persentase $84,37 \%$ dan rata-rata skor 25,31 ; (2) kemampuan representasi persamaan matematis siswa berupa model matematika pada materi program linear termasuk dalam kriteria sedang dengan persentase 65,9\% dan rata-rata skor 13,18; (3) kemampuan representasi kata-kata siswa berupa langkah-langkah penyelesaian masalah termasuk dalam kriteria rendah dengan persentase $47,44 \%$ dan rata-rata skor 23,72; dan (4) kemampuan representasi matematis siswa secara keseluruhan pada materi program linear termasuk dalam kriteria sedang dengan persentase $64,08 \%$ dan rata-rata skor 64,08 .

\section{REFERENSI}

Chandriyana, R. A., Sujadi, I., \& Riyadi. 2014. Representasi Matematis Siswa Kelas VII di SMPN 9 Yogyakarta dalam Membangun Konsep Sistem Persamaan Linear Dua Variabel. Jurnal Elektronik Pembelajaran Matematika: ISSN 2339-1685.

Eka,L. K. \& Ridwan, M.Y. 2017. Penelitian Pendidikan Matematika.Bandung: PT Rafika Aditama. National Council of Teachers of Mathematics. 2000. Principles and Standars for School Mathematics. Reston, VA: NCTM Publication.

Purnomo, Erdy. 2014. Pengaruh Pembelajaran Kooperatif Strategi Think-Talk-Write Menggunakan Masalah Kontekstual terhadap Kemampuan Representasi Matematis Siswa. Skripsi Jurusan Pendidikan Matematika UIN Syarif Hidayatullah Jakarta.

Surya, E. \& Istiawati. 2016. Mathematical Representation Ability in Private Class XI SMA YPI Dharma Budi Sidamanik. Jurnal Saung Guru: Vol. VIII, No. 2.

Suwaningsih, E. \& Misel. 2016. Penerapan Pendekatan Matematika Realistik untuk Meningkatkan Kemampuan Representasi Matematis Siswa. Metodi Didaktik: Vol. 10, No. 2.

Syafri, F. S. 2017. Kemampuan Representasi Matematis dan Kemampuan Pembuktian Matematika. Jurnal Edumath: ISSN Online 2356-2056. 